\title{
ANALISIS LAPORAN KEUANGAN UNTUK MENILAI KINERJA KEUANGAN PT MAYORA INDAH TBK TANGERANG
}

\author{
Agung Tri Putranto')
}

${ }^{1)}$ dosen universitas pamulang, email : agung.tputranto@gmail.com

\section{ARTICLES INFORMATION \\ JURNAL SEKURITAS \\ (Ekonomi, Keuangan dan Investasi ) \\ Vol.1, No.3, Maret 2018 Halaman : 1- 26 \\ (c) LPPM \& Prodi Manajemen UNVERSITAS PAMULANG \\ ISSN (online) : 2581-2777 ISSN (print) : :2581-2696}

\section{Keyword :}

Analisis Laporan Keuangan, Kinerja Perusahaan

JEL. classification :

C33, B26

\section{Contact Author :}

PRODI MANAJEMEN UNPAM

JL.Surya Kencana No.1 Pamulang

Tangerang Selatan - Banten

Telp. (021) 7412566, Fax (021) 7412491

Email :

jurnalfinance.unpam@gmail.com
Tujuan penelitian ini adalah untuk melihat perbandingan saldo-saldo yang dipandang berkaitan, yang dapat mencerminkan posisi keuangan perusahaan serta kinerja perusahaan tersebut. Perbandingan ini lebih dikenal dengan istilah rasio.

Metode penelitian yang digunakan adalah deskriptif kuantitatif yaitu data yang diperoleh dan di analisa dengan dasar teori yang ada sehingga memberikan suatu gambaran dan perhitungan yang cukup jelas.

Penilaian kinerja keuangan dalam penelitian ini menggunakan analisis rasio likuiditas yang terdiri dari Current Ratio dan Quick Ratio dan rasio profitabilitas yang terdiri dari profit Margin on Sales Ratio, Basic Earning Power Ratio, Return of Investment dan Return of Equity.

Berdasarkan hasil analisis yang dilakukan menunjukkan bahwa kinerja dan posisi keuangan dapat dikatakan cukup baik dari segi rasio likuiditasnya dan masih belum cukup baik dari segi rasio profitabilitasnya, sedangkan untuk rasio profitabilitasnya tingkat rasio masih di bawah rata-rata industri, sehingga dapat dikatakan perusahaan masih belum optimal dalam menghasilkan laba.

The purpose of this study is to see the comparison of balances that are deemed related, which may reflect the company's financial position as well as the performance of the company. This comparison is better known as the ratio term.

The research method used is descriptive quantitative data obtained and analyzed on the basis of existing theory so as to provide a clear picture and calculation.

Assessment of financial performance in this study using liquidity ratio analysis consisting of Current Ratio and Quick Ratio and profitability ratios consisting of profit Margin on Sales Ratio, Basic Earning Power Ratio, Return of Investment and Return of Equity. Based on the results of the analysis shows that the performance and financial position can be quite good in terms of liquidity ratio and still not good enough in terms of profitability ratios, while for profitability ratios the ratio is still below the industry average, so it can say the company is still not optimal in making a profit 


\section{A. Pendahuluan}

Salah satu cara yang dapat dilakukan perusahaan agar tetap perusahaan bertahan, yaitu dengan menginterpretasikan atau menganalisis keuangan, yang bertujuan untuk mengetahui keadaan dan perkembangan keuangan dari tahun ke tahun pada perusahaan yang bersangkutan. Dengan menganalisis laporan keuangan dari perusahaannya, akan dapat diketahui perkembangan usaha yang telah dicapai di waktuwaktu lalu dan waktu yang sedang berjalan. Dengan demikian dapat diketahui kelemahan-kelemahan dari perusahaan serta hasil-hasil yang dianggap cukup baik. Hasil analisa dapat digunakan oleh pemilik atau manajer perusahaan untuk perbaikan penyusunan rencana dan policy yang akan dilakukan di waktu yang akan datang. Mengetahui kelemahan-kelemahan laporan keuangan dapat diperbaiki, dan hasil yang cukup baik dapat dipertahankan di waktu yang akan datang.

Mengetahui kondisi kesehatan perusahaan juga sangat penting dilakukan oleh investor, bankers, maupun kreditor dalam pengambilan keputusan - keputusan investasi dan kreditnya. Mereka ini berkepentingan terhadap prospek keuntungan di masa mendatang, perkembangan perusahaan dan untuk mengetahui jaminan investasinya serta kondisi kerja atau kondisi keuangan jangka pendek perusahaan tersebut. Dari hasil analisa laporan keuangan tersebut investor, bankers dan kreditur akan dapat menentukan langkah-langkah yang harus ditempuhnya. Pemerintah pun sangat berkepentingan terhadap laporan keuangan perusahaan, di samping untuk menentukan besarnya pajak yang harus ditanggung oleh perusahaan juga sangat diperlukan oleh Badan Pusat Statistik (BPS), Dinas Perindustrian, Perdagangan dan Tenaga Kerja sebagai dasar perencanaan pemerintah.

Pentingnya dalam menganalisis suatu laporan keuangan secara menyeluruh adalah untuk menilai perbandingan saldo-saldo yang dipandang berkaitan, yang dapat mencerminkan posisi keuangan perusahaan serta kinerja perusahaan tersebut seperti bagaimana likuiditas keuangan perusahaan tersebut, kemampuan perusahaan tersebut dalam melunasi utang serta kemampuan perusahaan tersebut untuk menghasilkan laba dan hal lainnya, baik itu merupakan suatu kemajuan ataupun suatu kemunduran. Perbandingan inilah yang lebih dikenal dengan istilah rasio. Dalam penulisan skripsi ini dipergunakan data dari tahun-tahun sebelumnya sebagai bahan perbandingan.

Di samping itu bukan rahasia lagi bahwa perusahaan - perusahaan di negara berkembang menggunakan utang sebagai penggerak kinerja perusahaannya. Namun penggunaan utang ini juga dapat menjadi bumerang bagi perusahaan itu sendiri karena di satu sisi penggunaan utang ini dapat memacu kinerja perusahaan, tetapi di sisi lain hal ini dapat menjerumuskan perusahaan dalam belenggu lilitan utang atau perusahaan tersebut dalam mengalami kondisi kesulitan finansial (financial distress) dan bahkan juga dapat mengalami kebangkrutan jika utang tersebut tidak dikelola dengan benar.

Dari beberapa analisis rasio keuangan yang dapat digunakan dalam menilai kinerja keuangan di antaranya adalah analisis rasio likuiditas dan rasio profitabilitas. Analisis rasio likuiditas dapat digunakan untuk mengukur kemampuan likuiditas jangka pendek perusahaan dengan melihat aktiva lancar perusahaan relatif terhadap utang lancarnya, sedangkan rasio profitabilitas dapat digunakan untuk mengukur kemampuan perusahaan menghasilkan keuntungan pada tingkat penjualan, aset dan modal saham tertentu. Mamduh (2009:75). 
PT. Mayora Indah Tbk Merupakan perusahaan yang bergerak di bidang makana dan minuman olahan. Perusahaan ini perlu melakukan pengukuran kinerja dengan menggunakan rasio keuangan sehingga manajemen perusahaan. Selama ini pimpinan hanya melihat kinerja perusahaan dari segi labanya saja asumsi manajemen, apabila perusahaan menghasilkan laba yang tinggi artinya kinerja perusahaan telah baik, tetapi bila laba semakin menurun artinya kinerja perusahaan semakin buruk. Adapun sebagai gambaran dapat dilihat dari laporan laba rugi dan neraca PT. Mayora Indah Tbk beserta anak perusahaan periode 2012 sampai dengan 2016

Tabel 1.1

Hasil Perhitungan Rasio - Rasio Keuangan

Tahun 2012 - 2016

\begin{tabular}{|c|c|c|c|c|c|c|}
\hline \multirow{2}{*}{ Rasio } & \multicolumn{5}{|c|}{ Tahun } & \multirow{2}{*}{$\begin{array}{l}\text { Rata - } \\
\text { Rata }\end{array}$} \\
\hline & 2012 & 2013 & 2014 & 2015 & 2016 & \\
\hline \multicolumn{7}{|l|}{$\begin{array}{l}\text { Rasio } \\
\text { Likuiditas }\end{array}$} \\
\hline Rasio Cepat & $276,11 \%$ & $244.34 \%$ & $208.99 \%$ & $236,53 \%$ & $225,02 \%$ & $238 \%$ \\
\hline Rasio Lancar & $198,22 \%$ & $188,99 \%$ & $145,84 \%$ & $180,58 \%$ & $170,34 \%$ & $883 \%$ \\
\hline \multicolumn{7}{|l|}{$\begin{array}{l}\text { Rasio } \\
\text { Profitabilitas }\end{array}$} \\
\hline $\begin{array}{l}\text { Rasio Marjin } \\
\text { Laba Bersih }\end{array}$ & $7,07 \%$ & $8,77 \%$ & $2,76 \%$ & $8,55 \%$ & $7,33 \%$ & $6 \%$ \\
\hline Rasui BEP & $11,57 \%$ & $13,97 \%$ & $5,14 \%$ & $14,46 \%$ & $14,28 \%$ & $11 \%$ \\
\hline $\begin{array}{l}\text { Rasio } \\
\text { Pengembalian } \\
\text { Total Aktiva }\end{array}$ & $8,95 \%$ & $10,85 \%$ & $3,79 \%$ & $11,17 \%$ & $10,41 \%$ & $9 \%$ \\
\hline $\begin{array}{l}\text { Rasio } \\
\text { Pengembalian } \\
\text { Ekuitas }\end{array}$ & $24,21 \%$ & $26,75 \%$ & $9,53 \%$ & $20,74 \%$ & $25,91 \%$ & $21 \%$ \\
\hline
\end{tabular}

Hasil Analisis Rasio - Rasio Keuangan Untuk Mengetahui Kinerja dan Posisi Keuangan Perusahaan

a. Rasio Likuiditas (liquidity Ratio)

1. Rasio Lancar (Current Ratio)

Berdasarkan perhitungan dari current ratio yang terjadi pada PT Mayora Indah Tbk pada tahun 2012 sampai dengan tahun 2013 current ratio mengalami penurunan sebesar $31,77 \%$ dimana current rasio tahun 2012 sebesar $276,11 \%$ dan tahun 2013 sebesar 244,34\%. Penurunan tersebut disebakan oleh kenaikan hutang lancar pada PT Mayora Indah Tbk . dari tahun 2013 sampai dengan 2014 current rasio mengalami penurunan kembali sebesar $35,35 \%$ penurunan tersebut diakibatkan karean adanya kenaikan hutang lancar. Dan pada tahun 2014 sampai dengan tahun 2015 mengalami kenaikan sebesar 27,54\%, kenaikan tersebut 
disebabkan oleh aktiva lancar yang semakin meningkat sedangkan pada tahun 2015 sampai dengan 2016 current rasio menglami penurunan kembali sebesar $11,31 \%$.

\section{Rasio Cepat (Quick Ratio)}

Berdasarkan perhitungan dari quick ratio yang terjadi pada PT Mayora Indah Tbk pada tahun 2012 sampai dengan tahun 2013 quick ratio mengalami penurunan sebesar $9,23 \%$ penurunan ini disebabkan karena adanya penurunan persediaan pada PT Mayora Indah Tbk . pada tahun 2013 sampai dengan tahun 2014 quick ratio mengalami penurunan kembali sebesar $43,15 \%$. tahun berikutnya pada tahun 2014 sampai dengan tahun 2015 quick ratio mengalami kenaikan sebesar $34,74 \%$ kenaikan ini disebabkan karena adanya kenaikan aktiva lancar ,dan kemudian pada tahun 2015 sampai dengan 2016 quick ratio mengalami penurunan kembali sebesar $10,24 \%$ yang disebabkan karena adanya penurunan persediaan pada PT Mayora Indah Tbk.

\section{b. Rasio Profitabilitas (Profitabilitas Ratio)}

\section{Rasio Marjin Laba Bersih (Profit Margin on Sales Ratio)}

Berdasarkan perhitungan dari PMOS yang terjadi pada PT Mayora Indah Tbk pada tahun 2013 mengalami kenaikan sebesar 1,7\% bila dibandingkan dengan tahun 2012, kenaikan ini disebabkan karena laba bersih yang meningkat dan juga penjualan yang meningkat. Sedangkan tahun 2014 mengalami penurunan dari tahun 2013 yang PMOS nilainya 8,77\% turun menjadi 2,76\% tetapi pada tahun 2015 mengalami kenaikan yang begitu drastis sebesar 5,79\% yang disebabkan oleh naiknya laba bersih perusahaan dan pada tahun 2016 PMOS kembali mengalami penrunan sebesar $1,22 \%$.

\section{c. Rasio Laba Dasar (Basic Earning Power Ratio)}

Pada perhitungan rasio BEP di PT Mayora Indah Tbk tahun 2013 mengalami kenaikan sebesar $2.4 \%$ bila dibandingkan dengan tahun 2012, kenaikan ini disebabkan karena adanya Ebit yang meningkat. Pada tahun 2014 mengalami sebuah penurunan sebesar $8,83 \%$ yang disebabkan karea total aktiva yang meningkat. Pada tahun 2015 rasio BEP mengalami kenaikan kembali sebesar 9,32 dan pada tahun 2016 rasio BEP mengalami sedikit penurunan sebesar $0,18 \%$.

\section{Rasio Pengembalian Atas Total Aktiva atau ROA (Retrun on Assets Ratio) atau ROI (Retrun on Investment)}

Pada perhitungan rasio ROI tahu 2012 sampai dengan tahun 2013 mengalami kenaikan. Pada tahun 2012 rasio ROI 8,95\% sedangkan rasio ROI tahun 2013 naik menjadi 10,85\% akan tetapi rasio ROI tahun 2014 pada PT Mayora Indah Tbk sangat menurun sebesar $7,06 \%$ yang disebabkan karena adanya penurunan laba bersih, dan pada tahun 2014 sampai dengan tahun 2015 rasio ROI kembali mengalami kenaikan sebesar 7,38\%, kenaikan ini disebakan karena total aktiva yang meningkat sedangkan pada tahun 2016 kembali mengalami penurunan sebesar $0,76 \%$. 


\section{Rasio Pengembalian Atas Ekuitas atau ROE (Retrun on Equity Ratio)}

Pada perhitungan rasio ROE pada tahun 2012 sampai dengan tahun 2013 mengalami kenaikan sebsear $2,54 \%$ yang disebabkan karena adanya laba bersih yang meningkat. Pada tahun 2013 sampai dengan tahun 2014 rasio ROE turun menjadi 9,53\% hal ini disebabkan karena adanya penurunan pada laba bershi PT Mayora Indah Tbk, sedangkan dari tahun 2014 sampai dengan tahun 2016 terus mengalami kenaikan. Dan dapat disimpulkan bahwa rasio ROE dari tahun 2012 sampai dengan tahun 2016 mengalami fluktuasi dengan kecendrungan mengalami kenaikan di tahun terakhirnya yang menunjukan hingga perusahaan cukup baik dan meningkatkan laba bersih.

\section{Perumusan Masalah}

1. Bagaimana analisis laporan keuangan PT. Mayora Indah Tbk beserta Anak Perusahaan berdasarkan perhitungan rasio likuiditas?

2. Bagaimana analisis laporan keuangan PT. Mayora Indah Tbk beserta Anak Perusahaan berdasarkan perhitungan rasio profitabilitas?

\section{Tujuan Penelitian}

1. Untuk Mengetahui analisis laporan keuangan PT Mayora Indah Tbk beserta Anak Perusahaan berdasarkan perhitungan pada analisis rasio likuiditas.

2. Untuk Mengetahui analisis laporan keuangan PT Mayora Indah Tbk beserta Anak Perusahaan berdasarkan perhitungan pada analisis rasio profitabilitas.

\section{A. Landasan Teori}

\section{Laporan Keuangan}

\section{A. Pengertian Laporan Keuangan}

Laporan keuangan sebagai alat yang sangat penting untuk memperoleh informasi sehubungan dengan adanya pihak-pihak tertentu yang berkepentingan terhadap laporan keuangan tersebut. Laporan keuangan ini bertujuan untuk mengetahui kondisi dan posisi perusahaan pada saat ini atau dalam suatu periode tertentu. Biasanya laporan keuangan dibuat per periode, misalnya tiga bulan atau enam bulan untuk kepentingan intern perusahaan dan adapun untuk laporan lebih luas dilakukan 1 tahun sekali.

Laporan keuangan juga akan menentukan langkah apa yang dilakukan perusahaan sekarang dan ke depan, dengan melihat berbagai persoalan yang ada, baik kelemahan maupun kekuatan yang dimiliki perusahaan dalam memanfaat peluang yang ada dan menghadapi atau menghindari ancaman yang mungkin timbul sekarang dan dimasa yang akan datang.

Sehubungan dengan hal tersebut, untuk mendapatkan gambaran yang lebih jelas, maka beberapa ahli memberikan definisi-definisi laporan keuangan yang dapat membantu dalam pemahamannya.

Menurut Ikatan Akuntansi Indonesia (IAI) (2004:2) dalam Standar Akuntansi Keuangan menyebutkan bahwa laporan keuangan merupakan bagian dari proses pelaporan keuangan yang meliputi neraca, laporan laba rugi, laporan perubahan posisi keuangan, catatan dan laporan lain serta materi penjelas yang menunjukkan bagian integral dari laporan keuangan. 
Menurut Munawir (2007:5) dalam Analisa Laporan Keuangan yang dikutip dari Myer dalam Bukunya Financial Statment Analysis mengatakan bahwa laporan keuangan adalah dua daftar yang disusun oleh akuntan pada akhir periode untuk suatu perusahaan. Kedua daftar itu adalah daftar neraca atau daftar posisi keuangan dan daftar pendapatan atau daftar laba rugi dan telah menjadi kebiasaan bagi perseroan-perseroan untuk menambah daftar ketiga yaitu surplus atau daftar laba yang tak dibagikan (laba yang ditahan).

Sofyan S Harahap (2003:12) mengemukakan bahwa laporan keuangan menggambarkan kondisi kuenagan dan hasil usaha suatu perusahaan pada saat tertentu atau jangka waktu tertentu. Adapun jenis laporan keuangan yang lazim dikenal adalah neraca atau laporan laba rugi, atau hasil usaha, laporan arus kas, laporan perubahan posisi keuangan.

Berdasarkan pendapat Mamduh (2009:12) laporan keuangan pada dasarnya ingin melaporkan kegiatan-kegiatan perusahaan, kegiatan investasi, kegiatan pendanaan dan kegiatan operasional. Sekaligus mengevaluasi keberhasilan strategi perusahaan untuk mencapai tujuan yang ingin dicapai.

Analisis atas laporan keuangan pada hakikatnya adalah untuk mengadakan penelitian atas keadaan keuangan atau posisi keuangan perusahaan pada suatu saat dan perubahan posisi keuangan atau kemajuankemajuan suatu perusahaan melalui laporan keuangan yang bersangkutan.

\section{B. Tujuan Laporan Keuangan}

Secara umum laporan keuangan bertujuan untuk memberikan informasi keuangan suatu perusahaan, baik pada saat tertentu maupun pada periode tertentu. Laporan keuangan juga dapat disusun secara mendadak untuk kebutuhan perusahaan maupun secara berkala (rutin).

Menurut Standar Akuntansi Keuangan (2004:4) tujuan laporan keuangan sebagai berikut:

a) Menyediakan informasi yang menyangkut posisi keuangan, kinerja serta perubahan posisi keuangan suatu perusahaan yang bermanfaat bagi sejumlah pihak dalam pengambilan keputusan ekonomi.

b) Laporan keuangan juga menunjukkan apa yang dilakukan manajemen atas sumber daya yang dipercayakan kepadanya.

Sedangkan menurut Kasmir (2010:87) beberapa tujuan pembuatan laporan keuangan yaitu:

1. Memberikan informasi tentang jenis dan jumlah aktiva yang dimiliki perusahaan saat itu.

2. Memberikan informasi tentang jenis dan jumlah kewajiban dan modal yang dimiliki perusahaan saat itu.

3. Memberikan informasi tentang jenis dan jumlah pendapatan yang diperoleh pada suatu periode tertentu.

4. Memberikan informasi tentang jumlah biaya dan jenis biaya yang dikeluarkan perusahaan dalam suatu periode tertentu.

5. Memberikan informasi tentang perubahan yang terjadi terhadap aktiva, pasiva dan modal perusahaan

6. Memberikan informasi tentang kinerja manajemen perusahaan dalam suatu periode tertentu. 
7. Memberikan informasi tentang catatan atas laporan keuangan dan informasi keuangan lainnya.

\section{Analisa Laporan Keuangan}

Analisa laporan keuangan merupakan hubungan antara angka yang satu dengan yang lain. Menurut Dwi Prastoyo \& Rifka Julianty (2002:24) analisa laporan keuangan terhadap laporan keuangan, dengan tujuan untuk memberikan tambahan informasi kepada para pemakai laporan keuangan untuk pengambilan keputusan ekonomi, sehingga kualitas keputusan yang diambil akan menjadi lebih baik.

Menurut Sofyan S Harahap (2007:18) analisa laporan keuangan dilakukan denga tujuan sebagai berikut:

a. Screening

Analisa dilakukan dengan tujuan untuk mengetahui situasi dan kondisi perusahaan darinlaporan keuangan tanpa pergi langsung ke lapangan.

b. Understanding

Dilakukan dengan tujuan untuk memahami perusahaan, kondisi keuangan, dan hasil usahanya.

c. Forecasting

Analisa digunakan untuk meramalkan kondisi keuangan perusahaan dimasa yang akan datang.

d. Diagnosis

Analisa dimaksudkan untuk melihat kemungkinan adanya masalahmasalah yang terjadi baik dalam manajemen, operasi, keuangan, atau masalah lain dalam perusahaan.

e. Evaluation

Analisa dilakukan untuk menilai prestasi manajemen dalam mengelola perusahaan.

\section{Metode dan Tekhnik Analisa Laporan Keuangan}

Menurut Munawir (2007:36) ada dua metode analisa yang digunakan oleh setiap penganalisa laporan keuangan, yaitu analisa horizontal dan analisa vertical.

a. Analisa Horizontal adalah analisa dengan mengadakan pembandingan laporan keuangan untuk beberapa periode atau beberapa saat, sehingga akan diketahui perkembangannya. Metode horizontal ini disebut juga sebagai metode analisis dinamis.

b. Analisa vertical yaitu apabila laporan keuangan yang dianalisa hanya meliputi satu atau satu saat saja, yaitu dengan memperbandingkan antara pos yang satu dengan pos yang lainnya dalam laporan keuangan tersebut, sehingga hanya akan diketahui keadaan keuangan atau hasil operasi pada saat itu saja. Analisa vertikal ini disebut juga sebagai metode analisis yang statis karena kesimpulan yang dapat diperoleh hanya untuk periode itu saja tanpa mengetahui perkembangannya. 
laporan keuangan terdapat beberapa jenis tekhnik analisa laporan keuangan. Adapun jenis-jenis tekhnik analisa laporan keuangan yang dapat dilakukan adalah sebagai berikut:
a. Analisa perbandingan laporan keuangan
b. Analisa tren
c. Analisa persentase per komponen (Common Size)
d. Analisa sumber dan penggunaan dana
e. Analisa sumber dan penggunaan kas
f. Analisa rasio
g. Analisa laba kotor
h. Analisa titik impas (BEP)

\section{Analisis Rasio Keuangan}

\section{A. Pengertian Rasio Keuangan}

Berdasarkan pendapat Agnes Sawir(2005:6), untuk menilai kondisi keuangan dan prestasi perusahaan, analisis keuangan memerlukan beberapa tolak ukur. Tolak ukur yang sering dipakai adalah rasio atau indeks, yang menghubungkan dua data keuangan yang satu dengan yang lainnya.

Menurut pendapat Slamet Munawir (2002:37), analisa rasio adalah suatu metode analisa untuk mengetahui hubungan dari pos-pos tertentu dalam neraca atau laporan laba-rugi secara individu atau kombinasi dari kedua laporan tersebut. Artinya berdasarkan data-data yang terdapat dalam laporan keuangan baik dari neraca, laporan laba-rugi, maupun kedua-duanya dapat dihitung bermacam-macam jenis rasio yang dapat dipergunakan sebagai pedoman dalam pengambilan keputusan untuk kelangsungan hidup perusahaan.

\section{B. Kegunaan Rasio Keuangan}

Berdasarkan pendapat Agnes Sawir (2005:6), analisis rasio keuangan yang menghubungkan unsur-unsur neraca dan perhitungan laba-rugi dengan lainnya, dapat memberikan gambaran tentang sejarah perusahaan dan penilaian posisinya pada saat ini. Analisis rasio juga memungkinkan manajer keuangan memperkirakan reaksi para kreditor dan investor dan memberikan pandangan ke dalam tentang bagaimana kira-kira dana dapat diperoleh.

\section{Jenis Analisis Rasio Keuangan}

Menurut pendapat Agnes Sawir (2005:7), rasio-rasio dikelompokan kedalam lima kelompok dasar, yaitu: likuiditas, leverage, aktivitas, profitabilitas, dan penilaian. Sejumlah rasio yang tak terbatas banyaknya dapat dihitung, akan tetapi dalam prakteknya cukup digunakan beberapa jenis rasio saja.

Jenis analisis rasio keuangan menurut Agnes Sawir (2005:8-22) adalah sebagai berikut:

a. Rasio Likuiditas (Liquidity ratio) 
Merupakan rasio yang menggambarkan kemampuan perusahaan dalam memenuhi kewajibannya yang akan jatuh tempo.

Rasio Likuiditas yang umum digunakan yaitu:

1) Rasio Lancar (Current Ratio)

Rasio ini dihitung dengan membagi Aktiva lancer dengan Utang lancer. Rasio lancer merupakan bagian yang paling umum digunakan untuk mengatahui kesanggupan memenuhi kewajiban jangka pendek, karena rasio ini menunjukkan seberapa jauh tuntutan dari kreditor jangka pendek dipenuhi oleh aktiva yang diperkirakan menjadi uang tunai dalam periode yang sama denganjatuh tempo utang.

$$
\text { Rasio Lancar }=\frac{\text { Aktiva Lancar }}{\text { Utang Lancar }}
$$

Rasio lancar yang rendah biasanya dianggap menunjukkan terjadinya masalah dalam likuiditas. Sebaliknya suatu perusahaan yang rasio lancarnya terlalu tinggi juga kurang bagus karena menunjukkan banyakanya dana yang pada akhirnya dapat mengurangi kemampulabaan perusahaan.

2) Rasio Cepat (Quick Ratio)

Rasio ini dihitung dengan mengurangkan persediaan dari Aktiva lancer dan kemudian membagi hasilnya dengan Utang lancar.

$$
\text { Rasio Cepat }=\frac{\text { Aktiva Lancar }- \text { Persedian }}{\text { Utang Lancar }}
$$

Persediaan merupakan unsur aktiva lancer yang tingkat likuiditasnya rendah, sering mengalami fluktuasi harga, dan unsur aktiva lancer ini sering menimbulkan kerugian jika terjadi likuidasi. Jadi rasio cepat lebih baik dalam mengukur kemampuan suatu perusahaan dalam memenuhi kewajiban jangka pendeknya. Rasio cepat yang umumnya dianggap baik adalah 1 (satu).

b. Rasio Manajemen Utang (Solvability Ratio)

Rasio leverage mengukur tingkat solvabilitas suatu perusahaan. Rasio ini menunjukkan kemampuan perusahaan memenuhi segala kewajiban finansialnya seandainya perusahaan tersebut pada saat itu likuidasi. Dengan demikian solvabilitas berarti kemampuan perusahaan untuk membayar semua utang-utangnya, baik jangka panjang maupun jangka pendek.

1) Rasio Utang (Debt Ratio) 
Rasio ini dihitung dengan membagi Total Utang dengan Total Aktiva. Rasio ini memberikan tolak ukur seberapa besar total aktiva yang dimiliki oleh perusahaan yang dibiayai memalui penggunaan utang.

$$
\text { Rasio Hutang }=\frac{\text { Total Hutang }}{\text { Total Aktiva }}
$$

Rasio ini memperlihatkan peoporsi antara kewajiban yang dimiliki. Semakin tinggi presentasenya, cenderung semakin besar resiko keuangannya bagi kreditormaupun pemegang saham.

2) Rasio Laba terhadap Beban Bunga (Times Interest Earned Ratio)

Rasio ini dihitung dengan membagi Laba sebelum Pajak dan Beban Bunga/EBIT (Earning Before Income and Tax) dengan Beban Bunga.

$$
\text { Rasio Laba Terhadap Beban Bunga }=\frac{\text { EBIT }}{\text { Beban Bunga }}
$$

Rasio ini mengukur kemampuan pemenuhan kewajiban bunga tahunan dengan laba operasi (EBIT), sejauh mana laba operasi boleh turun tanpa meneyebabkan kegagalan dalam pemenuhan kewajiban membayar bunga pinjaman.

c. Rasio Manajemen Aktiva (Assets Manajement Ratio)

Merupakan rasio yang mengukur sejauh mana efektifitas manajeme perusahaan dalam mengelola persediaan bahan mentah, barang dalam proses, dan barang jadi serta kebijakan pemasaran. Rasio manajemen aktiva menganalisis hubungan antara laporan laba-rugi, khususnya penjualan dengan unsur-unsur yang ada pada neraca, khususnya unsurunsur aktiva. Rasio aktivitas ini diukur dengan istilah perputaran unsurunsur aktiva yang dihubungkan dengan penjualan.

Rasio-rasio aktivitas yang umum digunakan:

1) Rasio Perputaran Persediaan (Inventory Turnover Ratio)

Rasio ini dihitung dengan membagi Harga Pokok Penjualan dengan Rata-rata Persediaan. Sedangkan untuk menghitung periode rata-rata persediaan dihitung dengan membagi jumlah hari dalam setahunnya, dianggap 360 hari, dengan perputaran persediaan. Satu tahun dapat diasumsikan 360 hari atau 365 hari, kedua angka ini digunakan dalam lingkup keuangan dan perbedaannya tidak akan mempengaruhi keputusan yang dihasilkan.

$$
\text { Rasio Perputaran Persediaan }=\frac{\text { Harga Pokok Penjualan }}{\text { Rata }- \text { Rata Persedian }}
$$

$$
\text { Periode Rata }- \text { Rata Persediaan }=\frac{360 \text { hari }}{\text { Perputaran Persediaan }}
$$


Perputaran ini menunjukkan berapa kali jumlah persediaan barang dagang diganti atau dijual dalam suatu periode. Apabila perputaran persediaan barang itu cepat, maka tidak ada masalah bagi perusahaan. Sebaliknya, apabila perputaran persediaan barang lambat hal ini akan mengganggu kelangsungan hidup perusahaan. Karena untuk menyimpan barang tersebut akan memerlukan berbagai macam biaya sewa gedung, biaya pemeliharaan, biaya bunga, biaya kebakaran, dan lain-lain.

2) Rasio Perputaran Piutang (Account Receivable Turnover Ratio)

Rasio ini dihitung dengan membagi Penjualan dengan Rata-rata Piutang Usaha.

$$
\text { Rasio Perputaran Piutang }=\frac{\text { Penjualan }}{\text { Rata }- \text { Rata Piutang Usaha }}
$$

Periode Rata - Rata Piutang Usaha $=\frac{360 \text { Hari }}{\text { Perputaran Piutang Usah }}$

Apabila perusahaan menunjukkan perputaran piutang semakin tinggi, maka perusahaan tersebut mempunyai tingkat rasio yang baik. Oleh karena dana yang diinvestasikan dalam piutang itu rendah. Sebaliknya, kalau rasionya semakin rendah berarti dana yang diinvestasikan dalam piutang itu semakin tinggi, hal ini disebabkan oleh bagian kredit dan penagihan bekerja tidak efektif, ada perubahan dalam kebijakan pemberian kredit kepada pelanggan.

Dengan menggunakan perputaran piutang dagang dapat pula dihitung waktu rata-rata pengumpulan piutang tersebut, yaitu dengan membagi jumlah hari dalam setahun, dianggap 360 hari, dengan tingkat perputaran piutang tersebut. Semakin besar hari penagihan piutang, semakin besar pula resiko piutang tidak dapat ditagih.

3) Rasio Perputaran Total Aktiva (Total Assets Turnover Ratio)

Rasio ini dihitung dengan membagi Penjualan dengan Rata-rata Total Aktiva.

$$
\text { Rasio Perputaran Total Aktiva }=\frac{\text { Penjualan }}{\text { Rata }- \text { Rata Total Aktiva }}
$$

Rasio ini menunjukkan efektifitas penggunaan seluruh harta perusahaan dalam rangka menghasilkan penjualan atau menggambarkan berapa rupiah penjualan bersih yang dapat dihasilkan oleh setiap rupiah yang diinvestasikan dalam bentuk harta persahaan. Kalau perputarannya lambat, ini menunjukkan bahwa aktiva yang dimiliki terlalu besar dibandingkan dengan kemampuan untuk menjual.

d. Rasio Profitabilitas (Profitability Ratio) 
Kemampulabaan (prifitabilias) merupakan hasil akhir bersih dari berbagai kebijakan dan keputusan manajemen. Rasio kemampulabaan akan memberikan jawaban akhir tentang efektifitas manajemen perusahaan, rasio ini memberi gambaran tentang tingkat efektifitas pengelolaan perusahaan.

Rasio profitabilitas yang umum digunakan:

1) Rasio Marjin Laba Bersih (Profit Margin on Sales Ratio)

Rasio ini dihitung membagi Laba Bersih dengan Penjualan. Rasio ini mengukur laba bersih setelah pajak terhadap penjualan.

2) Rasio Daya Laba vasar (Dastc Larmmtry Peverjualan

Rasio ini dihitung dengan membagi Laba Sebelum Pajak dan BiayaBunga/EBIT (Earning Before Income and Tax) dengan Total Aktiva. Rasio ini menunjukkan kemampuan menghasilkan laba dari aktiva perusahaan, sebelum pengaruh pajak serta bunga. Rasio ini sangat berguna untuk membandingkan perusahaan dengan situasi pajak yang berbeda dan tingkat bunga yang berbeda.

$$
\text { Basic Earning Power } \frac{\text { EBIT }}{\text { Total Aktiva }}
$$

3) Rasio Pengembalian atas Total Aktiva atau ROA (Return on Assets Ratio).

ROA sering disamakan dengan ROI (Return on Invesment). Rasio ini dihitung dengan Total Aktiva. Rasio ini menunjukkan seberapa banyak laba bersih yang dapat diperoleh dari seluruh kekayaan yang dimiliki perusahaan.

$$
\text { ROI }=\frac{\text { Laba Bersih }}{\text { Total Aktiva }}
$$

4) Rasio Pengembalian atas Ekuitas atau ROE (Return on Equity Ratio)

Rasio ini dihitung dengan membagi Laba Bersih dengan Ekuitas. Rasio ini memperlihatkan sejauh manakah perusahaan mengelola modal sendiri secara efektif, mengukur tingkat keuntungan dari investasi yang telah dilakukan pemilik modal sendiri atau pemegang saham perusahaan.

$$
\text { ROE }=\frac{\text { Laba Bersih }}{\text { Ekuitas }}
$$


e. Rasio Penilaian Pasar (Valuation Ratio)

Sekumpulan rasio yang menghubungkan harga saham perusahan dengan laba dan nilai buku per saham.

Rasio Penilaian yang umum digunakan:

1) Rasio harga terhadap laba atau PER (Price to Earning Ratio)

Rasio harga per saham terhadap laba per saham.

$$
\text { Rasio Harga Terhadap Laba }=\frac{\text { Harga Saham }}{\text { Laba Per Saham }}
$$

2) Rasio Harga Pasar terhadap Nilai Buku (Market to Book Ratio) Rasio harga pasar saham terhadap nilai bukunya.

$$
\text { Rasio Harga Pasar Terhadap Nilai Buku }=\frac{\text { Harga Pasar }}{\text { Nilai Buku Per Saham }}
$$

\section{Rasio Likuiditas}

Menurut Mamduh (2009:75) rasio likuiditas mengukur kemampuan likuiditas jangka pendek dengan melihat aktiva lancarperusahaan relatif terhadap utang lancarnya (utang dalam hal ini merupakan kewajiban perusahaan). Meski rasio ini tidak bicara masalah solvabilitas (kewajiban jangka panjang) dan biasanya relatif tidak penting dibandingkan dengan rasio solvabilitas, tetapi rasio likuiditas yang buruk dalam jangka panjang juga akan mempengaruhi solvabilitas perusahaan. Dua rasio likuiditas jangka pendek yang sering digunakan adalah rasio lancar dan rasio quick (sering juga disebut acid test ratio)

\section{E. Rasio Profitabilitas}

Menurut Mamduh (2009:75) Rasio ini mengukur kemampuan perusahaan menghasilkan keuntungan (profitabilitas) pada tingkat penjualan asset, dan modal saham tertentu. Ada tiga rasio yang sering dibicarakan, yaitu: profit margin, return on total asset (ROA) dan return on equity (ROE). Profit margin menghitung sejauh mana kemampuan perusahaan menghasilkan laba bersih pada tingkat penjualan tertentu. Rasio ini bisa dilihat secara langsung pada analisis common size untuk laporan laba rugi. Rasio profitabilitas yang lain adalah Return On Total Asset (ROA). Rasio ini mengukur kemampuan perusahaan menghasilkan laba bersih berdasarkan tingkat asset yang tertentu. ROA juga seringdisebut sebagai ROI (Return On Invesment). Rasio profitabilitas yang lain adalah Return On Equity (ROE), Rasio ini mengukur kemampuan perusahaan menghasilkan laba berdasarkan modal saham tertentu. Rasio ini merupakan ukuran profitabilitas dari sudut pandang pemegang saham. 


\section{B. Metodologi}

Penelitian yang dilakukan penulis, sesuai dengan masalah yang akan dibahas tentang analisis kinerja keuangan perusahaan maka dapatlah diektahui jenis penelitian adalah deskriptif dengan pendekatan kuantitatif. Pengertian diskriptif dengan kuantitatif. Pengertian deskriptif yaitu metode penelitian yang dimaksud untuk menggambarkan sesuatu yang diteliti, kemudian menganalisis untuk memberikan alternative penyelesaian dari massalah yang diteliti :

Adapun ciri - ciri metode diskriptif :

a. Memusatkan diri pada pemecahan masalah - masalah yang ada pada masa sekarang dan masalah - masalah yang actual.

b. Data yang dikumpulkan mula mula disusun, diolah, dijelaskan, dan kemudian di analisis.

Profitabilitas mengukur kemampuan perusahaan menghasilkan keuntungan (profitabilitas) pada tingkat penjualan, asset, dan modal saham yang tertentu. Ada beberapa rasio profitabilitas yang dapat digunakan :

1. Rasio Marjin Laba Bersih adalah rasio yang mengukur laba bersih setelah pajak terhadap penjualan.

2. Rasio Daya Laba Dasar adalah rasio yang mengukur kemampuan menghasilkan laba dari aktiva perusahaan, sebelum pengaruh pajak serta bunga.

3. Rasio pengembalian atas Total Aktiva atau ROA atau juga bisa disebut ROI adalah rasio yang menunjukkan seberapa banyak laba bersih yang dapat diperoleh dari seluruh kekayaan yang dimiliki perusahaan.

4. Rasio Pengembalian atas Ekuitas atau REO adalah rasio yang memperlihatkan sejauh manakah perusahaan mengelola modal sendiri secara efektif, mengukur tingkat keuntungan dari investasi yang telah dilakukan pemilik modal sendiri atau pemegang saham perusahaan.

Kinerja keuangan merupakan presentasi yang dicapai perusahaan dalam suatu periode tertentu yang mencerminkan tingkat kesehatan perusahaan tersebut.

Tingkat kesehatan perusahaan dapat di ukur dengan menggunakan standar rasio menurut Fred Weston yang dikutip oleh Kasmir (2008:129) sebagai berikut :

1. Rasio Likuiditas (Liquidity Ratio)

\begin{tabular}{|c|c|c|c|c|}
\hline & \multirow{2}{*}{$\begin{array}{c}\text { Standar } \\
\text { Rata - rata }\end{array}$} & \multicolumn{3}{|c|}{ Kategori } \\
\hline & & Tidak Sehat & Cukup Sehat & $\begin{array}{c}\text { Sangat } \\
\text { Sehat }\end{array}$ \\
\hline Current Ratio & 2 kali & $0 \mathrm{~s} / \mathrm{d}<2$ & $\geq 2$ & $>2$ \\
\hline Quick Ratio & 1,5 kali & $0 \mathrm{~s} / \mathrm{d}<1,5$ & $\geq 1,5$ & $>1,5$ \\
\hline Cash Ratio & $50 \%$ & $0 \mathrm{~s} / \mathrm{d}<50 \%$ & $\geq 50 \%$ & $>50 \%$ \\
\hline Cash Turn Over & $10 \%$ & $0 \mathrm{~s} / \mathrm{d}<10 \%$ & $\geq 10 \%$ & $>10 \%$ \\
\hline $\begin{array}{l}\text { Inventory to net } \\
\text { working capital }\end{array}$ & $12 \%$ & $0 \mathrm{~s} / \mathrm{d}<12 \%$ & $\geq 12 \%$ & $>12 \%$ \\
\hline
\end{tabular}


2. Rasio Profitabilitas (Profitability Ratio)

\begin{tabular}{|l|c|c|c|c|}
\hline & \multirow{2}{*}{$\begin{array}{c}\text { Standar } \\
\text { Rata - rata }\end{array}$} & Tidak Sehat & Cukup Sehat & $\begin{array}{c}\text { Sangat } \\
\text { Sehat }\end{array}$ \\
\cline { 3 - 5 } & & & $\geq 20 \%$ & $>20 \%$ \\
\hline Net Profit Margin & $20 \%$ & $0 \mathrm{~s} / \mathrm{d}<20 \%$ & $\geq 30 \%$ & $>30 \%$ \\
\hline Retrun On Investment & $30 \%$ & $0 \mathrm{~s} / \mathrm{d}<30 \%$ & $\geq 40 \%$ & $>40 \%$ \\
\hline & $40 \%$ & $0 \mathrm{~s} / \mathrm{d}<40 \%$ & $\geq 40 \%$ \\
\hline
\end{tabular}

\section{Hasil dan Pembahasan}

\section{Gambaran Umum Objek Penelitian}

\section{a. Sejarah Singkat Perusahaan}

PT Mayora Indah Tbk (Perusahaan) didirakan pada tanggal 17 Februari 1997 berdasarkan akta No. 204 yang diubah dengan akta No. 320 tanggal 22 Juni 1997,keduanya dibuat dihadapan Notaris Poppy Savitri Parmanto S.H., sebagai pengganti dari Notaris Ridwan Suselo S.H., notaris di Jakarta. Akta pendirian tersebut telah mendapat pengesahan dari Mentri Kehakiman Republik Indonesia dalam Surat Keputusan No. V.A.5/5/14 tanggal 3 januari 1978 dan telah di daftarkan pada kantor Kepaniteraan Pengadilan Negri Tangerang No. 2/PNTNG/1978 tanggal 10 januari 1978 serta diumumkan dalam Berita Negara RI NO. 39 tanggal 15 Mei 1990, Tambahan No. 1716.

Anggaran dasar perusahaan diubah dengan akta No. 421 tertanggal 30 Desember 1989 dan diubah kembali dengan akta No. 155 tertanggal 16 Januari 1990, keduanya dibuat dihadapan S.P. Henny Sidkhi S.H., notaris di Jakarta dan telah mendapatkan pengesahaan dari Mentri Kehakiman Republik Indonesia No C2-1696.HT.01.04.TH.90 tertanggal 26 Maret 1990. Anggaran Dasar Perusahaan juga diubah secara menyeluruh dengan akta No. 49 tertanggal 4 april 1990 dibuat dihadapan S.P. Henny Sidkhi S.H., notaris di Jakarta dan telah mendapat pengesahaan dari Mentri Kehakiman Republik Indonesia berdasarkan surat keputusan No. C2-2609.HT.01.04.TH.90 tertanggal 7 Mei 1990. Perubahan tersebut antara lain meningkatkan modal dasar perusahaan dari Rp. 20.000.000.000,- (dua puluh miliyar rupiah) menjadi Rp. 30.000.000.000,- (tiga puluh miliyar rupiah) yang terbagi atas Rp. 30.000 .000 ,- (tiga puluh juta rupiah) saham biasa dengan nilai nominal Rp. 1.000 ,- per saham.

Anggaran dasar perusahaan telah mengalami beberapa kali perubahan, yang terakhir denagn akta Notaris Adam Kasdarmadji S.H., No. 448 tanggal 27 Juni 1997, antara lain mengenai maksud dan tujuan perusahaan. Akata perubahan ini telah mendapat persetujuan dari Menteri Kehakiman Republik Indonesia dala Surat Keputusan No. C2-620.HT.01.04 ${ }^{\mathrm{TH}} .98$ tanggal 6 Februari 1998.

Pada tanggal 25 Mei 1990, perusahaan memperoleh persetujuan dari Mentri Keuangan Republik Indonesia dengan Surat Keputusan No. SI109SHM/MK.10/1990 untuk menawarkan 3.000.000 saham kepada masyarakat 
melalui Bursa Efek pada tanggal 4 Juli 1990. Adapun tujuan perusahaan menawarkan sebagian dari modal sahamnya kepada masyarakat melalui Bursa Efek di Indonesia antara lain untuk memperkuat struktur permodalan perusahaan dengan cara pengurangan kewajiban jangka panjang, meningkatkan kegiatan usaha dengan ekspansi atau perluasan di bidang makan ringan dan memberikan kesempatan kepada masyarakat luas baik perorangan maupun lembaga/badan usaha untuk memiliki sahm perusahaan.

Selanjutnya pada tanggal 16 Oktober 1992, perusahaan memperilehsurat dari Ketua Badan Pengawasan Pasar Modal No. S-1710/PM/1992, perihal pemberitahuan efektifnya pernyataan pendaftaran perusahaan, atas penawaran umum terbatas kepada pemegang saham sebanyak 63.000 .000 saham, yang mulai tercatat di Bursa Efek Indonesia dan Surabaya pada tanggal 30 Desember 1992.

Pada tanggal 7 Februari 1994, perusahaan memperoleh surat dari Ketua Badan Pengawasan Pasar Modal No. S-219/PM/1994 perihal pemberitahuan efektifnya pernyataan pendaftaran perusahaan atas penawaran umum terbatas 11 kepada para pemegang saham sebanyak 24.570 .000 saham, yang mulai tercatat di Bursa Efek Indonesia dan Surabaya pada tanggal 1 Maret 1994. Pada tanggal 31 Desember 2004 seluruh saham perusahaan sejumlah 766.584.000 saham telah tercatat pada Bursa Efek Indonesia dan Surabaya.

Pada tanggal 26 Mei 1997, perusahaan memperoleh surat dari Ketua Badan Pengawas Pasar Modal No. 001/MI/V/97 perihal pemberitahuan efektifnya pernyataan pendaftaran perusahaan atas penawaran umum obligasi kepada masyarakata sebesar Rp. 300.000.000,- pad atingkat bunga tetap sebesar $14,65 \%$ per tahun. Seluruh obligasi dijual dengan harga nilai nominal dan dicatat di Bursa Efek Surabaya. Pada tahun 2004 obligasi dilunasi perusahaan. Pada tanggal 27 Juni 2003, perusahaan memperoleh surat dari Ketua Badan Pengawasan Pasar Modal No. S-1542/PM/2003 perihal pemberitahuan efektifnya pernyataan pendaftaran perusahaan atas penawaran umum obligasi kepada masyarakat sebesar Rp. 200.000.000,- pada tingkat bunga tetap sebesar $14 \%$ per tahun. Seluruh obligasi dijual dengan harga nilai nominal dan dicatat di Bursa Efek Surabaya.

Perusahaan berdomisili di Tangerang denga pabrik berlokasi Tangeran dan Bekasi. Kantor pusat perusahaan beralamat di Gedung Mayora, Jl. Tomang Raya No. 21-23, Jakarta 11440. Perusahaan mulai beroperasi secara komersial pad bulan Mei 1978. Jumlah karyaawan perusahaan dan anak perusahaan pada tanggal 31 Desember 2003,2004 dan 2005 masing masing adlah 4.310 karyawan,4650 karyawan dan 5.317 karyawan. Perusahaan tergabung dalam kelompok usaha (group) Mayora. Perusahaan juga merupakan induk perusahaan dengan memiliki, baik secara langsung maupun tidak langsung, lebih dari $50 \%$ sham anak perusahaan berikut :

a. PT. Sinar Pangan Barat (SPB) yang berdomisili di Medan. Jenis perusahaan industry makanan dan olahan, mulai beroperasi sejak tahun 1991. 
b. PT. Sinar Pangan Timur (SPT) yang berdomisili di Surabaya. Jenis usahanya industry makanan dan olahan, mulai beroperasi sejak tahun 1992.

c. PT. Torabika Eka Semesta (TES) yang berdomisili di Tangerang. Jenis usahanya industry pengolahan kopi bubuk dan instan, mulai beroperasi sejak tahun 1990.

d. PT. Kakao Mas Gemilang (KMG) dimiliki TES dengan kepemilikan 96\%, berdomisili di Tangerang. Jenis usahanya industry pengolahan biji kakao, mulai beroperasi sejak tahun 1985.

e. Mayora Nederland B.V, berdomisili di Bealanda. Yang jenis usahanya jasa keuangan dan mulai beroperasi sejak tahun 1996.

\section{b. Bidang Usaha Perusahaan}

Sesuai dengan pasal 3 anggaran dasar perusahaan, ruang lingkup kegiatan perusahaan adalah menjalankan usaha dalam bidang industri, perdagangan serta agen/perwakilan. Saat ini perusahaan menjalankan bidang usaha industry makanan olahan, antara lain biscuit, kembang gula, wafer, cokelat, dan jelly. Produk - produk perusahaan telah memasuki pasar dan telah mendapat tempat yang baik dikalangan konsumen makanan ringan. Untuk menjangkau seluruh lapisan konsumen telah diciptakan berbagai macam produk dengan nama, kualitas dan harga yang berbeda.

Beberapa merk dagangan dari perusahaan yang telah dikenal masyarakat anatar lain adalah :

a. Biskuit : Roma (dalam berbagai jenis), Danisa (dalamm berbagai jenis) dan Better.

b. Kembang Gula : Kopiko, Swissel, Kiss, Pee Wee, Tamrin, dan lain - lain.

c. Wafer : Roma Chocolate Wafer, Sando, Beng - Beng, Astor, dan lain- lain.

d. Cokelat : Choki - Choki, Hits, Oka, dan lain - lain.

e. Jelly : Long Jelly.

Selain itu perusahaan juga memproduksi produk - produk sejenis untuk ekspor dengan menggunakan merk - merk yang berbeda. Bahan - bahan utama yang dipergunakan oleh perusahaan dalam memproduksi produk produk diatas antara lain.

a. Tepung (gandum, tapioca, beras, jagung)

b. Minyak (minyak kelapa, minyak kelapa sawit, misyak kedelai, minyak cokelat, memtega, dll)

c. Gula

d. Susu

e. Cokelat, kopi

f. Bahan - bahan pembukus dll.

Perusahaan tidak mengalami kesulitan dalam pembelian atas bahan baku yang dipergunakan karena lebih dari $90 \%$ bahan - bahan tersebut dihasilkan di dalam negeri. Bahan baku yang masih di import oleh perusahaan adalah "flavor" (pengharum) yang diguanakn pada produk seperti kemabang gula dan jelly. 
Untuk menjaga kualitas produk, perusahaan telah mendirikan laboratorium untuk setiap unit produk yang dihasilkan dengan melakukan penelitian tidak banyak pada produk akhir tetapi juga bahan - bahan baku yang dipergunakan. Laboratorium, sebagai contoh melaksanakan percobaan terhadap seluruh bahan baku . lebih jauh lagi laboratorium juga melaksanakan percobaan guna menghindarikan perencanaan terhadap produk yang akan dibuat.

Selain menjaga kualitas produk yang akan dihasilkan, laboratorium perusahaan juga berfungsi sebagai pusat pengembangan produk - produk baru tersebut berdasarkan atas hasil penelitian dikalangan konsumen menegenai jenis atau rasa yang tengah digemari oleh konsumen.

Untuk meningkatkan pelayanan pemasaran dan kemudahan jalur distribusi, perusahaan telah menyerahkan masalah tersebut kepad PT. Inbisco Niaga yang bertindak sebagi pemasok dan distribusi tunggal perusahaan. PT. Inbisco Niaga didirikan oleh Inbisco Group pada tahun 1985 sebagai salah satu group perusahaan Inbisco Group, baik pasar domestic maupun ekspor.

Pada saat ini PT. Inbisco Niaga memeiliki kantor cabang di seluruh Indonesia yang dilengkapi dengan sarana pergudangan, administrasi, armada distribusi danpenjualan untuk menyebarluaskan produk - produk perusahaan di seluruh Indonesia. Dengan adanya PT Inbisco Niaga,, perusahaan berhasil menembus pasaran ekspor seperti Singapura, Hongkong, Timur Tengah, AS,Canada, dan Eropa.

2. Kinerja Dan Posisi Keuangan PT. Mayora Indah Tbk Beserta Anak Perusahaan Pada Tahun 2012, 2103, 2014, 2015, dan 2016 Berdasarkan Analisa Rasio Likuiditas dan Profitabilitas

Perhitungan rasio - rasio keuangan PT.Mayora Indah Tbk beserta Anak Perusahaan berdasarkan pada data laporan keuangan tahun 2012 sampai dengan 2016 PT. Mayora Inda Tbk beserta Anaka Perushaan yang telah tersedia, laporan keuangan tersebut terdiri dari Neaca dan Laporan Laba Rugi.

Berikut ini adalah perhitungan rasio - rasio keuangan PT.Mayora Indah Tbk beserta Anak Perusahaan berdasarkan rasio likuiditas dan profitabilitas.

\section{a. Rasio Likuiditas (Liquidity Ratio)}

Pengertian likuiditas menurut Fred Weston dalam Kasmir, (2008:129) menjelaskan sebagai berikut. Rasio likuiditas merupakan rasio yang menggambarkan kemampuan perusahaan dalam memenuhi kewajiban (utang) jangka pendeknya dengan standar rasio sebagai berikut :

\begin{tabular}{|l|l|l|l|}
\hline \multirow{2}{*}{ Rasio-rasio } & \multicolumn{3}{|c|}{ Kategori } \\
\cline { 2 - 4 } & Tidak Sehat & Cukup Sehat & Sangat Sehat \\
\hline Current Ratio & $<150 \%$ & $150 \%$ s/d $200 \%$ & $>200 \%$ \\
\hline Quick Ratio & $<150 \%$ & $150 \%$ s/d $200 \%$ & $>200 \%$ \\
\hline
\end{tabular}

1. Rasio Lancar (Liquidity Ratio), dengan rumus :

$$
\text { Rasio Lancar }=\frac{\text { Aktiva Lancar }}{\text { Utang Lancar }} \times 100 \%
$$




$$
\begin{aligned}
\text { Tahun } 2012 & =\frac{5.313 .599 .558 .516}{1.924 .434 .119 .144} \times 100 \% \\
& =278,11 \%
\end{aligned}
$$

Tahun $2013=\frac{6.430 .065 .428 .871}{2.631 .646 .469 .682} \times 100 \%$

$=244,34 \%$

$$
\begin{aligned}
\text { Tahun } 2014= & \frac{6.508 .768 .623 .440}{3.114 .337 .601 .361} \times 100 \% \\
& =208,99 \%
\end{aligned}
$$

$$
\begin{aligned}
\text { Tahun } 2015= & \frac{7.454 .347 .029 .087}{3.151 .495 .162 .694} \times 100 \% \\
& =236,53 \%
\end{aligned}
$$

$$
\begin{aligned}
\text { Tahun } 2016 & =\frac{8.739 .782 .750 .141}{3.884 .051 .319 .005} \times 100 \% \\
& =225,02 \%
\end{aligned}
$$

Tabel 4.3

Perhitungan Rasio Lancar (Current Ratio)

\begin{tabular}{|l|l|l|l|}
\hline Tahun & Aktiva Lancar & Utang Lancar & Rasio Lancar \\
\hline 2012 & 5.313 .599 .558 .516 & 1.924 .434 .119 .144 & $276,11 \%$ \\
\hline 2013 & 6.430 .065 .428 .871 & 2.631 .646 .469 .682 & $244,34 \%$ \\
\hline 2014 & $6^{508} .768 .623 .440$ & 3.114 .337 .601 .361 & $208,99 \%$ \\
\hline 2015 & 7.454 .347 .029 .087 & 3.151 .495 .162 .694 & $236,53 \%$ \\
\hline 2016 & 8.739 .782 .750 .141 & 3.884 .051 .319 .005 & $225,02 \%$ \\
\hline
\end{tabular}




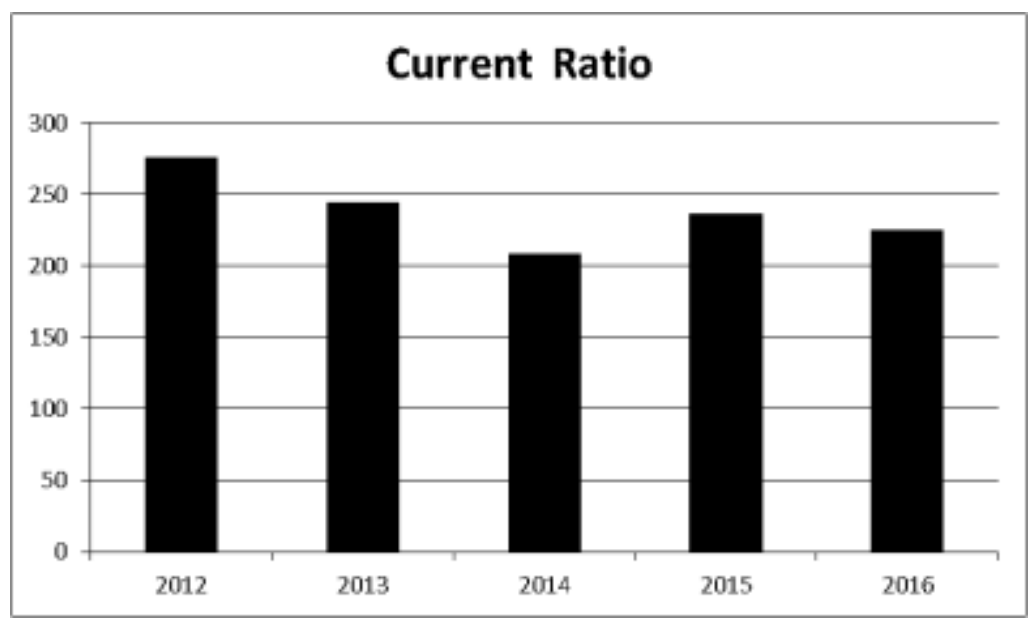

Gambar 4.3

Grafik Rasio Lancar (Current Ratio)

2. Rasio Cepat (Quick Ratio), dengan rumus :

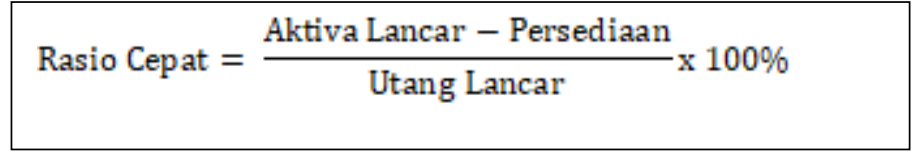

Tahun $2012=\underline{5.313 .599 .558 .516-1.498 .989 .460 .205} \times 100 \%$ 1.924.434.119.144

$=198,22 \%$

Tahun $2013=\underline{6.430 .065 .428 .871-1.456 .454 .215 .049} \times 100 \%$ 2.631.646.469.682

$=188,99 \%$

Tahun $2014=\frac{6.508 .768 .623 .440-1.966 .800 .644 .217}{3.114 .337 .601 .361} \times 100 \%$

$=145,84 \%$

Tahun $2015=7.454 .347 .029 .087-1.763 .233 .048 .130 \times 100 \%$ $=180,58 \%$

Tahun $2016=\frac{8.739 .782 .750 .141-2.123 .676 .041 .546}{3.884 .051 .319 .005} \times 100 \%$ 3.884.051.319.005 $=170,34$

Tabel 4.4

Perhitungan Rasio Cepat (Quick Ratio)

\begin{tabular}{|l|l|l|l|l|}
\hline Tahun & Aktiva Lancar & Persediaan & Utang Lancar & Rasio Cepat \\
\hline 2012 & 5.313 .599 .558 .516 & 1.498 .989 .460 .205 & 1.924 .434 .119 .144 & $276,11 \%$ \\
\hline 2013 & 6.430 .065 .428 .871 & 1.456 .454 .215 .049 & 2.631 .646 .469 .682 & $244,34 \%$ \\
\hline 2014 & 6.508 .768 .623 .440 & 1.966 .800 .644 .217 & 3.114 .337 .601 .361 & $208,99 \%$ \\
\hline 2015 & 7.454 .347 .029 .087 & 1.763 .233 .048 .130 & 3.151 .495 .162 .694 & $236,53 \%$ \\
\hline 2016 & 8.739 .782 .750 .141 & 2.123 .676 .041 .546 & 3.884 .051 .319 .005 & $225,02 \%$ \\
\hline
\end{tabular}


Gambar 4.4

\section{Quick Ratio}

250

200

150

100

50

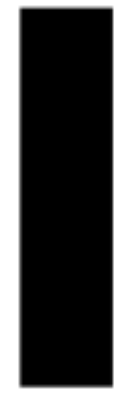

2012

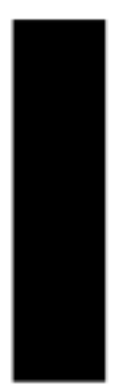

2013

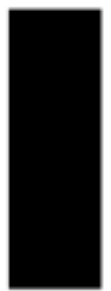

2014

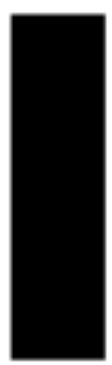

2015

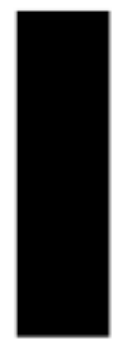

2016

Grafik Rasio Cepat (Quick Ratio)

3. Rasio Pengembalian Atas Total Aktiva atau ROA (Return on Assets Ratio) atau ROI (return on Investment), dengan rumus :

$$
\text { Rasio ROI }=\frac{\text { Laba Bersih }}{\text { Total Aktiva }} \times 100 \%
$$

Tahun 201

$$
\begin{aligned}
& =\frac{724.836 .954 .804}{8.302 .506 .241 .903} \times 100 \% \\
& =8,95 \%
\end{aligned}
$$

Tahun 2013

$$
\begin{aligned}
& =\frac{1053 . .624 .812 .412}{9.709 .838 .250 .473} \times 100 \% \\
& =10,85 \%
\end{aligned}
$$

Tahun 2014

$$
=390.727 .052 .364 \times 100 \%
$$$$
\text { 10.297.997.020.540 }
$$

$=3,79 \%$

Tahun 2015

$$
\begin{aligned}
& =\frac{1.266 .519 .320 .600}{11.342 .715 .686 .221} \times 100 \% \\
& =11,17 \%
\end{aligned}
$$

Tahun $2016=1.345 .716 .806 .578 \times 100 \%$ 
Table 4.7

\begin{tabular}{|l|l|l|l|}
\hline Tahun & Laba Bersih & Total Aktiva & ROI Ratio \\
\hline 2012 & 724.836 .954 .804 & 8.302 .506 .241 .903 & $8,95 \%$ \\
\hline 2013 & 1.053 .624 .812 .412 & 9.709 .838 .250 .473 & $10,85 \%$ \\
\hline 2014 & 390.727 .052 .364 & 10.297 .997 .020 .540 & $3,79 \%$ \\
\hline 2015 & 1.266 .519 .320 .600 & 11.342 .715 .686 .221 & $11,17 \%$ \\
\hline 2016 & 1.345 .716 .806 .578 & 12.922 .421 .859 .142 & $10,41 \%$ \\
\hline
\end{tabular}

Perhitungan Rasio ROA atau ROI

Gambar 4.7

Grafik Pengembalian Atas Total Aktiva atau ROA (Retrun on Assets Ratio) atau ROI (Retrun on Investment)

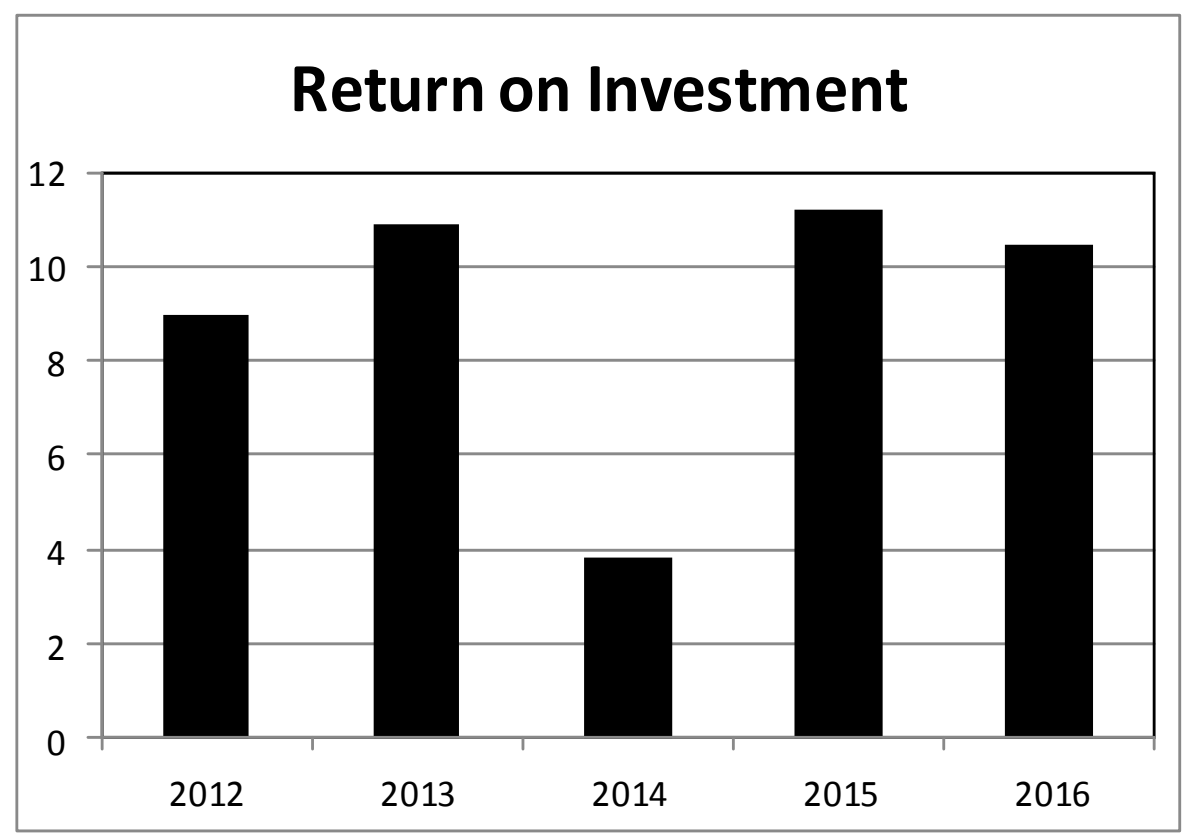


4. Rasio Pengembalian Atas Ekuitas atau ROE (Return on Equity Ratio), dengan rumus :

$$
\begin{aligned}
& \text { Rasio ROE }=\frac{\text { Laba Bersih }}{\text { Ekuitas }} \times 100 \% \\
& \text { Tahun } 2012=\frac{724.836 .954 .804}{3.067 .850 .327 .238} \times 100 \% \\
& =24,21 \% \\
& \text { Tahun } 2013 \\
& =\underline{1.053 .624 .812 .412} \times 100 \% \\
& \text { 3.938.760.819.650 } \\
& =26,75 \% \\
& \text { Tahun } 2014 \\
& =390.727 .052 .364 \times 100 \% \\
& \text { 4.100.554.992.789 } \\
& =9,53 \% \\
& =\underline{1.266 .519 .320 .600} \times 100 \% \\
& \text { 6.265.255.987.065 } \\
& =20,74 \% \\
& \text { Tahun } 2016 \\
& =\underline{1.345 .716 .806 .578} \times 100 \% \\
& \text { 5.194.459.927.187 } \\
& =25,91 \%
\end{aligned}
$$

Tabel 4.8

Perhitungan Rasio Pengembalian Atas Ekuitas atau ROE (Retrun on Equity Ratio)

\begin{tabular}{|l|l|l|l|}
\hline Tahun & Laba Bersih & Ekuitas & ROE Ratio \\
\hline 2012 & 724.836 .954 .804 & 3.067 .850 .327 .238 & $24,21 \%$ \\
\hline 2013 & 1.053 .624 .812 .412 & 3.938 .760 .819 .650 & $26,75 \%$ \\
\hline 2014 & 390.727 .052 .364 & 4.100 .554 .992 .789 & $9,53 \%$ \\
\hline
\end{tabular}




\begin{tabular}{|l|l|l|l|}
\hline 2015 & 1.266 .519 .320 .600 & 6.265 .255 .987 .065 & $20,74 \%$ \\
\hline 2016 & 1.345 .716 .806 .578 & 5.194 .459 .927 .187 & $25,91 \%$ \\
\hline
\end{tabular}

Gambar 4.8

Grafik Rasio Pengembalian Atas Ekuitas Atau ROE (Retrun on Equity Ratio)

\section{Return on Equity Ratio}

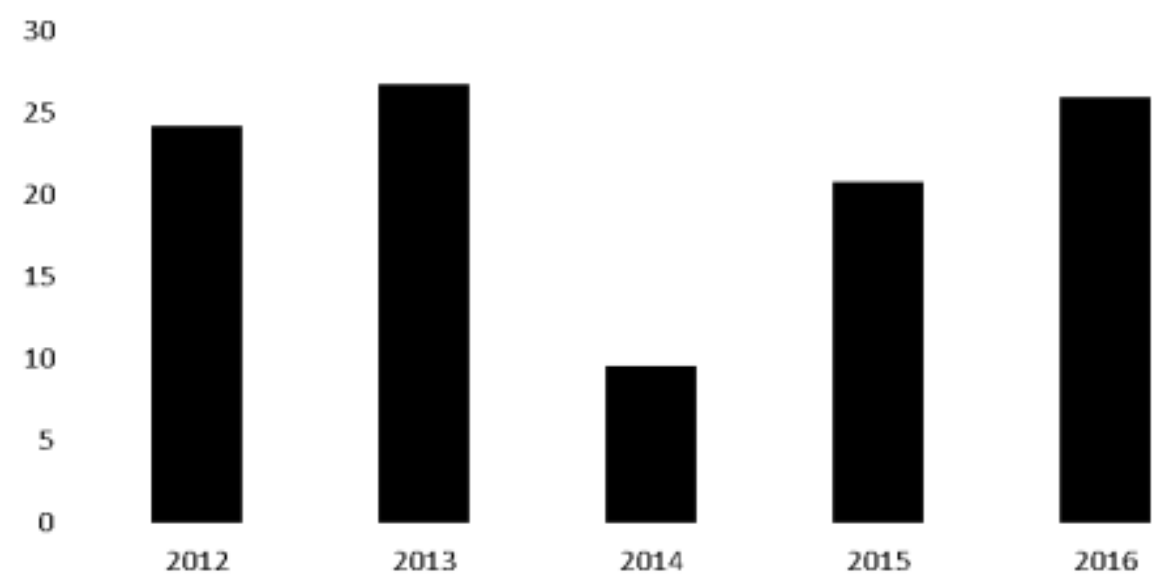

\section{Kesimpulan}

1. Tingkat Rasio Likuiditas PT Mayora Indah Tbk

Bila dilihat dari hasil perhitungan Current Rato dan Quick Ratio maka tingkat liquiditas PT Mayora Indah Tbk dalam keadaan baik, karena tingkat rasio lancar selama 5 tahun terakhir masih berada diatas standar umum yang menunjukan bahwa dengan menggunakan aktiva lancar yang dimiliki perusahaan mampu memenuhi kewajiban jangka pendeknya dengan baik dan tingkat rasio cepat mengalami fluktuasi dengan kecendrungan mengalami penurunan dari tahunterakhirnya. meskipun rasio perusahaan berfluktuatif, selama 5 tahunterakhir masih berada diatas standar umum yang menunjukan bahwa dengan menggunakan aktiva yang dimiliki perusahaan mampu memenuhi kewajiban jangka pendenknya dengan baik.

2. Tingkat Rasio Profitabilitas PT Mayora Inda Tbk

Berdasarkan hasil perhitungan PMOS pada 5 tahun tersakhir mengalami penurunan di tahun terakhirnya meskipun begitu rasio ini menunjukan kinerja perusahaan cukup baik dalammenghasilkan laba dari setiap penjualannya . kemudian pada rasio BEP pada 5 tahun terakhir dapat disimpulkan bahwa perusahaani ni cenderumh mengalami kenaikan dan pada rasio BEP ini menunjukan perusahaan cukup baik dalam menghasilkan EBIT dari setiap total aktivanya. Dan pada rasio $\mathrm{ROI}$ dapat disimpulkan bahwa $\mathrm{ROI}$ cenderung menglami kenaikan yang ditunjukan kinerja perusahaan cukup baik dalam 
menghasilkan laba disetiap total aktivanya. Dan yang terakhir rasio ROE dapat disimpulkan bahwa mengalami fluktuasi yang cenderung meningkat di tahun terakhirnya yang menunjukan kinerja perusahaan cukup baik dalam meningkatkanlaba bersih dari setiap modal yang diivestasikannya, meskipun pad 5 tahun terakhir ini terjadi kenaikan namun tingkat rasio profitabilitasnya masih dibawah rata - rata industry.

3. Dari ringkasan perhitungan rasio diatas menunjukan bahwa kinerja keuangan perusahaan PT Mayora Indah Tbk dapat dikatakan cukup baik bila dilihat dari tingkat rasio likuiditas, sedangkan bila dilihat dari tingkat rasio profitabilitas perusahaan masih belum cukup baik dalam menghasilkan laba.

\section{E. Daftar Pustaka}

Brigham,E.F. \& Houston,J.F. 2001. "Manajemen Keuangan”. Edisi kedelapan Jakarta: Erlangga.

Edisi sebelas , Jakarta: Salemba Empat.

2010. "Dasar - Dasar Manajemen Keuangan".

Darsono \& Ashari. 2005. "Pedoman Praktis Memahami Laporan Keuangan”. Yogyakarta: Andi.

Harahap, Sofyan S.2007. "Analisis Kritis atas Laporan Keuangan”. Edisi kesatu. Jakarta : PT. Raja Grafindo Persada

Horne,J.C.V \& Wachowicz, J.M 2005. “Prinsip - Prinsop Manajer Keuangan”.Edisi 12 (diterjemahkan oleh Fitriasari, D \&Kwary, D.A). Jakarta Salemba Empat.

Ikatan Akuntansi Indonesia. 2004. "Standar Akuntansi Keuangan”. Salemba Emapat.

Jumingan. 2006. "Analisis Laporan Keuangan”. Jakaarta: Bumi Aksara.

Kasmir, 2009. “Analisis Lapora Keuangan”. Jakarta: Rajawali Pers.

Mamduh, M. Hanafi. 2009. "Analisis Laporan Keuangan”. Yogyakarta : UPP STIM YKPN.

Mulyadi, 2001. "Balanced Scorecard : atau Manajemen Kontemporer Untuk Pelipatgandan Kinerja Keuangan Perusahaan". Yoarta. Salemba Empat.

Munawir, S. 2007. “Analisa Laporan Keuangan”. Edisi Keempat. Liberty.Yogyakarta.

2002. "Analisa Laporan Keuangan”. Liberty. Yogyakarta.

Nardi Sunardi (2017), "Determinan Kebijakan Utang serta Implikasinya terhadap Kinerja Perusahaan (Perusahaan yang tergabung dalam index LQ.45 yang terdaftar di Bursa Efek Indonesia)" Jurnal Sekuritas (Saham, Ekonomi, Keuangan dan Investasi), ISSN (online) : 2581-2777 \& ISSN (print) : 2581-2696 , Vol.1, No.1, September 2017, Hal. 78-97.

Prastowo, Dwi, Rifka Julianty. 2002. "Analisis Laporan Keuangan - Konsep dan Aplikasi”. Cetakan Kedua. Yogyakarta: AMP YKPN. 
Riyanto, Bambang. 2001. “Dasar - Dasar Pembelajaran Perusahaan”. BPFE. Yogyakarta.

Sartono, Agus. 2001. "Manajemen Keuangan Teori dan Aplikasi”. Edisi Keempat. Yogyakarta: Penerbit BPFE

Sawir, Agnes. (2005). "Analisis Kinerja Keuangan dan Perencanaan Keuangan Perusahaan". PT Gramedia Pustaka Utama, Jakarta.

Sugiono, Arief. 2009. "Manajemen Keuangan untuk Praktisi Keuangan”. Jakarta: Grasindo.

Sugiyono. 2010. “Metode Penelitian Kuantitatif , Kualitatif dan R\&D”. Bandung: Alfabeta.

Weston J. Fred dan Copeland E. Thomas.2009. "Manajemen Keuangan”. Edisi Sembilan. Jakarta: Binarupa Aksara.

2010. "Pengantar Manajemen Keuangan". Jakarta: Kencana. http://jurnalakuntansikeuangan.com/2014/04/menghitung-danmenginterpretasikan-rasio-laporan-keuangan/,21 April 2014. d.m.wikipedia.org/wiki/Rasio_finansial. 